\title{
Comparison between electrocautery and fibrin selant after hepatectomy in rats
}

\section{Estudo comparativo entre eletrocautério e selante de fibrina após hepatectomia em ratos}

Tâmara Rúbia Cavalcante Guimarães Coutinho'; Osvaldo Malafala, ECBC-PR'; Orlando Jorge Martins Torres, TCBC-MA²;

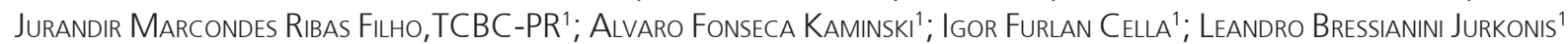

\section{A}

\begin{abstract}
Objective: To compare between electrocautery and fibrin sealant hemostasis in rats after partial hepatectomy. Methods: we used 24 Wistar rats, which were submitted to $30 \%$ hepatic resection, divided into two groups of 12 animals each: Group Electrocautery and Group Tachosil $\circledast$. These animals were evaluated after three and 14 days. We assessed the presence of complications, laboratory tests and histological exam of the recovered liver. Results: the presence of abscess was more prevalent in the electrocautery group. The observed adhesions were more pronounced in the electrocautery group, both in frequency and in intensity, after three and 14 days. There were no deaths in either group. As for laboratory analysis, after three days the hematocrit was lower in the TachoSil ${ }^{\circledR}$ Group. The elevation of AST and ALT were more pronounced in the electrocautery group $(p=0.002$ and $p=0.004)$ in three days. Histological analysis of specimens collected on the third day after surgery showed similar results in both groups for the presence of polymorphonuclear cells, whereas mononuclear was more evident in the TachoSil@ group. We also observed that angiogenesis, although present in both

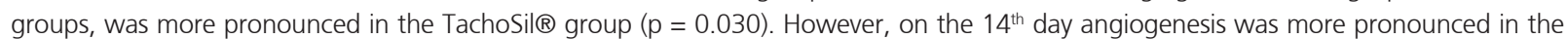
electrocautery group, but without statistical significance. Conclusion: hemostasis achieved by the groups was similar; however, the use of electrocautery was associated with infections, adhesions at higher grades and elevated liver enzymes.
\end{abstract}

Key words: Hepatectomy. Rats. Electrocoagulation. Fibrin.

\section{INTRODUCTION}

iver surgery had its beginning in ancient times, consolidating from the increase in the knowledge of the anatomy and physiology of the liver. The development of specific anesthesia routines, evolution of pre- and postoperative care, ventilatory and hemodynamic support and also conducting of operations in specialized centers are directly related to the decreased the rates of morbidity and mortality ${ }^{1,2}$. The risks include liver failure, infection, biliary fistula and massive bleeding ${ }^{3}$, the latter being the most dreaded by surgeons.

Aiming to improve hemostasis, different techniques have been used in the repair of hepatic tissue, including mechanical and thermal actions, pharmacotherapy, topic agents and tissue adhesives, with different actions in the hemostatic process ${ }^{4}$.

The use of topical hemostatics has its advantages by reducing the need for blood transfusions, promoting better visualization of the surgical field, decreasing operating time and reducing mortality. They are available in several configurations and their choice should take into consideration the type of operation, cost, amount of bleeding, experience and preference of the surgeon and also adverse events ${ }^{4}$.

To define the ultimate hemostatic of the hepatic parenchyma is difficult; however, it is necessary to identify the one that best fits the proposed procedure, seeking to reduce mortality.

This work aimed to compare electrocautery hemostasis with fibrin sealant in rats after partial hepatectomy.

\section{METHODS}

The study was approved by the Ethics in Animal Experimentation Committee of Veterinary Medicine School, State University of Maranhão, under Protocol 039/2012.

We used 24 Wistar, male rats, randomly distributed into two groups of 12 animals: Electrocautery Group (EG) and TachoSil Group (TG). Each was subdivided into two subgroups, depending on the day of sacrifice: three and 14 days.

After anesthesia with ketamine and xylazine animals were placed in supine position in a operative board

1. Post-Graduation Program in Principles of Surgery, Faculdade Evangélica do Paraná / Hospital Universitário de Curitiba / Instituto de Pesquisas Médicas, Curitiba, Paraná - PR, Brazil; 2. Hospital São Domingos, São Luis, Maranhão, Brazil. 
and underwent longitudinal laparotomy from $1 \mathrm{~cm}$ below the xiphoid process in the craniocaudal direction; then we to proceeded to exposure of the median lobe and hepatic resection, corresponding to approximately $30 \%$ of the total liver volume.

In EG animals we performed the resection with monopolar electrocautery; in the $\mathrm{TG}$, by cutting with scissors.

In EG, epilation of the back of the animal was held in the dimensions of about $3 \times 2 \mathrm{~cm}$ to promote contact with the plate of the electrocautery. We used the electrocautery WEM, Model SS-601 MC for hemostasis, at zero cutting and 15 watts coagulating, for two minutes. In the TG we applied the hemostatic in the dimensions of $2 \times 2 \mathrm{~cm}$ on the wound surface, followed by local compression for two minutes.

In the third and $14^{\text {th }}$ days postoperatively half of each group was reoperated and an submitted to an inventory of the cavity in search of hematomas, collections, infections, abscesses, fistulas and adhesions. Subsequently, the whole liver was removed, weighed and processed for histological analysis, all the specimens being analyzed by a single pathologist. Adhesions were classified by the Nair score ${ }^{5}$.

The blood collection was made by the puncture of the caudal vena cava, picking up approximately $5 \mathrm{ml}$ of blood for leukocytes, hematocrit, aspartate aminotransferase (AST), alanine aminotransferase (ALT), gamma glutamyl transferase (Gamma-TG) and alkaline phosphatase .

Death was caused by exsanguination, and those animals surviving this procedure received anesthetic overdose with four times the dose for induction of anesthesia.

The normality of data distribution was assessed by the Shapiro-Wilk test. Normal laboratory variables were alkaline phosphatase, hematocrit and leukocytes; the abnormal variables were aspatate aminotransferase, alanine aminotransferase, gamma glutamyl transferase. We used the Wilcoxon and Student $t$ tests for comparisons within the same group, and the Mann-Whitney and Student $t$ tests for comparison between groups. The microscopic variables - polymorphonuclear and mononuclear cells, congestion, edema and angiogenesis - were analyzed by Fisher's exact test. The results of the degrees of variable intensity were pooled and divided into two groups, considering the intensity from 0 to 1 as none / Mild, and 2 to 3 as moderate to intense. The level of significance for the null hypothesis was $5 \%(p<0.05)$

\section{RESULTS}

No death occurred in the animals subjected to hepatectomy with hemostasis in any groups.

Regarding the presence of collections and abscesses in the animals of EG, there was abscess in 16.6\% of those who underwent reoperation on the third day, and $33 \%$ in the ones reoperated on the $14^{\text {th }}$. No animal from TG presented with collections or abscesses.

As for adhesions, we found a preponderance of adhesions at higher grades in EG both on the third and $14^{\text {th }}$ postoperative days.

When comparing animals on the third day postoperatively, the worst values of leukocytes and hematocrit were observed in EG. In the statistical analysis, only the hematocrit showed significant difference. As for aminotransferases, both had significant increase in EG with a significant difference between groups; alkaline phosphatase and Gamma-TG showed no significant difference between groups (Table 1).

Table 1 - Comparison of laboratory tests of animals undergoing hepatectomy with hemostasis promoted by electrocautery

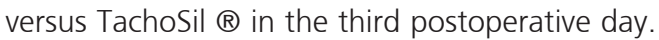

\begin{tabular}{|c|c|c|c|c|}
\hline Variable & Group & Average & Standard deviation & $\mathrm{p}$ \\
\hline Leukocytes & GE & 9.85 & 3.23 & 0.248 \\
\hline$(\mathrm{mil} / \mathrm{mL})$ & GT & 7.55 & 1.81 & \\
\hline Hematocrit & GE & 39.25 & 3. 59 & $0.001 *$ \\
\hline (\%) & GT & 29.50 & 1.64 & \\
\hline AST & GE & 264.33 & 53.70 & $0.002 *$ \\
\hline (u/L) & GT & 169.83 & 48.03 & \\
\hline ALT & GE & 125.33 & 43.95 & $0.004 *$ \\
\hline (u/L) & GT & 71.50 & 22.11 & \\
\hline FA & GE & 246.33 & 205.89 & 0.634 \\
\hline$(\mathrm{u} / \mathrm{L})$ & GT & 289.83 & 67.67 & \\
\hline GGT & GE & 2.33 & 1.03 & 0.180 \\
\hline$(\mathrm{u} / \mathrm{L})$ & GT & 2.50 & 1.37 & \\
\hline
\end{tabular}

$E G$ = animals undergoing operation with hemostasis promoted by electrocautery; TG = animals undergoing operation with hemostasis promoted by TachoSil $@$.

* significance 
On the $14^{\text {th }}$ postoperative day, hematologic function showed no difference between EG and TG groups. There was a marked worsening of liver function in EG, but there was no difference between groups. As for alkaline phosphatase and gamma-TG, although there was a significant increase of the former in TG, it was not statistically significant (Table 2).

Histological variables in EG and TG groups were compared on the third day postoperatively. The presence of polymorphonuclear cells was similar in both groups; however, the mononuclear cells, as well as angiogenesis, were more evident in TG(Table 3).

On the $14^{\text {th }}$ day after hepatectomy, the result was similar for the presence of polymorphonuclear cells in both groups. However, angiogenesis was more pronounced in the electrocautery group (Table 4).

\section{DISCUSSION}

the complications inherent to hepatectomy, postoperative bleeding has been a decisive factor of morbidity. It occurs due to the characteristics of the liver tissue, such as friability, Intense vascularization, absence of smooth muscle to can cause vasoconstriction, making it difficult to control bleeding ${ }^{3}$. This motivated this research, in an attempt to determine methods to promote hemostasis after trauma and liver resections.

The choice rats as an experimental model was made due to easy availability and handling, greater resistance to infections, longer survival and lower cost.

Liver resection consisted of removal of $30 \%$ of the liver, so that it could not only simulate changes due to

Table 2 - Comparison of laboratory tests of animals undergoing hepatectomy with hemostasis promoted by electrocautery versus TachoSil $\circledast$ in the $14^{\text {th }}$ postoperative day.

\begin{tabular}{|c|c|c|c|c|}
\hline Variable & Group & Average & Standard deviation & $\mathrm{p}$ \\
\hline Leukocytes & GE & 8.96 & 1.17 & 0.352 \\
\hline$(\mathrm{mil} / \mathrm{mL})$ & GT & 6.80 & 1.66 & \\
\hline Hematocrit & GE & 32.17 & 2.38 & 0.220 \\
\hline (\%) & GT & 41.20 & 1.47 & \\
\hline AST(u/L) & GE & 220.33 & 39.95 & 0.120 \\
\hline$(\mathrm{u} / \mathrm{L})$ & GT & 127.83 & 10.72 & \\
\hline ALT(u/L) & GE & 88.50 & 9.81 & 0.085 \\
\hline$(\mathrm{u} / \mathrm{L})$ & GT & 70.00 & 5.51 & \\
\hline $\mathrm{FA}(\mathrm{u} / \mathrm{L})$ & GE & 258.83 & 140.67 & 0.172 \\
\hline$(\mathrm{u} / \mathrm{L})$ & GT & 408.67 & 64.21 & \\
\hline GGT & $\mathrm{GE}$ & 1.50 & 0.83 & 0.710 \\
\hline$(\mathrm{u} / \mathrm{L})$ & GT & 2.33 & 1.03 & \\
\hline
\end{tabular}

$E G$ = animals undergoing operation with hemostasis promoted by electrocautery; TG = animals undergoing operation with hemostasis promoted

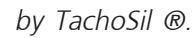

Table 3 - Microscopic analysis of specimens from animals submitted to hepatectomy with hemostasis promoted by electrocautery versus Tachosil $\AA^{\circledR}$ in the third postoperative day.

\begin{tabular}{|c|c|c|c|c|}
\hline & Classification & Electrocautery Group(\%) & Tachosil @ Group(\%) & $p$ \\
\hline \multirow[t]{2}{*}{ Polymorphonuclear } & Absent/Mild & 16.7 & 16.7 & 0.773 \\
\hline & Moderate/Intense & 83.3 & 83.3 & \\
\hline \multirow[t]{2}{*}{ Mononuclear } & Absent/Mild & 83.3 & 50 & 0.273 \\
\hline & Moderate/Intense & 16.7 & 50 & \\
\hline \multirow[t]{2}{*}{ Congestion } & Absent/Mild & 66.7 & 33.3 & 0.284 \\
\hline & Moderate/Intense & 33.3 & 66.7 & \\
\hline \multirow[t]{2}{*}{ Edema } & Absent/Mild & 16.7 & 16.7 & 0.773 \\
\hline & Moderate/Intense & 83.3 & 66.7 & \\
\hline \multirow[t]{2}{*}{ Angiogenesis } & Absent/Mild & 100 & 33.3 & $0.030 *$ \\
\hline & Moderate/Intense & & 66.7 & \\
\hline
\end{tabular}

* significance 
Table 4 - Microscopic analysis of specimens from animals submitted to hepatectomy with hemostasis promoted by Tachosil ${ }^{\circledR}$ versus electrocautery in the $14^{\text {th }}$ postoperative day.

\begin{tabular}{|c|c|c|c|c|}
\hline & Classification & Electrocautery Group(\%) & TachoSil @ Group(\%) & $\mathrm{p}$ \\
\hline \multirow[t]{2}{*}{ Polymorphonuclear } & Absent/Mild & 66.7 & 33.3 & 0.284 \\
\hline & Moderate/Intense & 33.3 & 66.7 & \\
\hline \multirow[t]{2}{*}{ Mononuclear } & Absent/Mild & 100 & 83.3 & 0.500 \\
\hline & Moderate/Intense & & 16.7 & \\
\hline \multirow[t]{2}{*}{ Congestion } & Absent/Mild & 83.3 & 83.3 & 0.773 \\
\hline & Moderate/Intense & 16.7 & 16.7 & \\
\hline \multirow[t]{2}{*}{ Edema } & Absent/Mild & 33.3 & 33.3 & 0.284 \\
\hline & Moderate/Intense & 66.7 & 66.7 & \\
\hline \multirow[t]{2}{*}{ Angiogenesis } & Absent/Mild & 33.3 & 66.7 & 0.284 \\
\hline & Moderate/Intense & 66.7 & 33.3 & \\
\hline
\end{tabular}

hepatectomy, but also reduce the number of deaths resulting from major resection.

In this study both the techniques applied in EG and TG were able to promote hemostasis, with no death due to massive bleeding.

In animals in which the electrocautery was used, there was coagulation necrosis during hepatic injury, and the presence of collections and abscesses was $16.6 \%$ and $25 \%$, respectively. A study comparing dry electrocautery with plastered one with different agents also showed an area of coagulation necrosis, though without intra-abdominal infections ${ }^{5}$. There were no detectable signs of infection of any kind in TG.

Regarding the presence of adhesions in TG, 33\% of the animals did not display it and, when present, were low-grade ones. When analyzing the adhesions in EG, only one animal did not present with them (9\%), and among those who had them, they were high-grade ones. In a study that analyzed the effects of bismuth subgalate, Arroyo et al. ${ }^{6}$ found adhesions after using dry cautery in $80 \%$ of the sample. Simões et al. ${ }^{7}$ conducted a study on mice that assessed hemostasis using dry electrocautery or electrocautery plastered with lidocaine or glycerin, and found that adhesions occurred in $83.3 \%$ of those in which dry electrocautery was used, and in $100 \%$ of those with plastered cautery.

Among the known tests used to evaluate liver function, the most commonly used are the aminotransferases - alanine aminotransferase, aspartate aminotransferase -, Gamma-TG and alkaline phosphatase. These are enzymes that spill over into the circulation after disruption of the membrane of hepatocytes due to cellular stresses. The aminotransferases are indicative of hepatocellular disease, being sensitive in the diagnosis of acute hepatocellular necrosis and commitment; however, the ALT - exclusively cytoplasmic - is more specific to liver disease than AST, since it is found almost exclusively in hepatocytes ${ }^{2}$. In the presence of acute liver injury, there is immediate increase in the levels of ALT, its detection becoming possible within a few hours, with a decrease during the days after trauma ${ }^{8}$. Several studies support this feature of ALT. According to Lee et al. ${ }^{9}$, in the analysis of 248 cases of hepatic resections performed without the Pringle maneuver, the mean peak of ALT occurred on the first day postoperatively. Silva et al. ${ }^{10}$, when evaluate the advantages and disadvantages of partial vascular occlusion of the liver during partial hepatectomy, found peak aminotransferase levels at 24 hours postoperatively. In this study, in EG there was an important aminotransferase increase, an even steeper rise being observed on the third day when compared with $14^{\text {th }}$ day post-hepatectomy. However, only ALT levels showed statistical differences. A similar finding was observed by Oliveira et al. ${ }^{11}$, who evaluate the effect of laser beam on remaining livers after $90 \%$ hepatectomy, having found higher levels of ALT in the first 24 hours, with a statistically significant difference between 24 and 72 hours. Regarding AST, there was no statistical difference between the different groups. When we compared the ALT levels in the third with $14^{\text {th }}$ days, we observed that while both were at levels above normal, on the $14^{\text {th }}$ there was a reduction in serum value. Alkaline phosphatase and Gamma-TG are serum markers of cholestasis processes, being important in the diagnosis of liver diseases ${ }^{12}$. In this work the values of alkaline phosphatase and Gamma-TG were within normal limits, demonstrating the lack of a cholestatic disease.

As for the hematological values, the hematocrit remained within the normal range for the species, both in TG and in EG. However, there was a Mild reduction on the third day after resection, and this fact may be related to bleeding during surgery. The leukocytes were within the normal range for the species in both groups. In this study, the leukocytes were good markers for infectious processes with respect to the TG, since there was no presence of abscesses or collections. However, in EG, despite the levels of leukocytes being normal, this was not confirmed in the macroscopic analysis, which showed the presence of infection. Carvalho et al. ${ }^{13}$, when investigating the 
hematological and metabolic consequences of colectomy combined with partial hepatectomy in rats, found a significantly greater increase in the levels of AST, ALT and alkaline phosphatase in the colectomy and hepatectomy group than in the colectomy alone group, suggesting that hepatectomy was responsible for such enzyme elevation.

The histological examination of the specimens of the third day following hepatic resection observed in TG a predominance of mononuclears - important markers of chronic inflammation - in a moderate to severe degree.
After 14 days, the result was similar for the presence of polymorphonuclear cells in the two groups. Angiogenesis, however, was more pronounced in EG.

In conclusion, hemostasis during liver resection was possible both with the use of electrocautery and TachoSil $\circledast$. Nonetheless, the presence of collections, abscesses, adhesions and elevation of AST / ALT enzymes were more pronounced in the electrocautery group three days after the procedure. Electrocautery stimulated more angiogenesis.

\title{
R E S U M O
}

\begin{abstract}
Objetivo: comparar a hemostasia entre eletrocautério e selante de fibrina em ratos submetidos à hepatectomia. Métodos: foram utilizados 24 ratos Wistar submetidos à ressecção hepática de 30\%, divididos em dois grupos contendo 12 animais cada: Grupo Eletrocautério e Grupo TachoSil@. Estes animais foram aferidos após três e 14 dias. Avaliou-se presença de complicações, exames laboratoriais e estudo histológico do fígado recuperado. Resultados: presença de abscesso foi mais prevalente no Grupo Eletrocautério. As aderências foram observadas mais pronunciadas no Grupo Eletrocautério tanto em frequência e intensidade, após três e 14 dias.

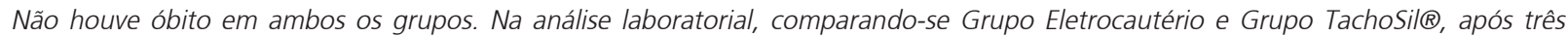
dias o hematócrito foi menor no Grupo TachoSil $\circledast$. A elevação das enzimas AST e ALT foram mais pronunciadas no Grupo Eletrocautério $(p=0,002$ e p=0,004) em três dias. Na análise histológica, no terceiro dia do pós-operatório, resultado semelhante foi

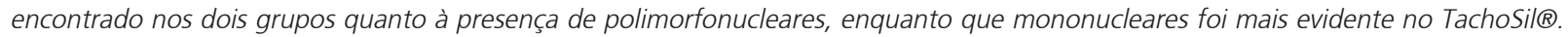
Observou-se ainda que a angiogênese, embora presente nos dois grupos, foi mais acentuada no Grupo TachoSil $(p=0,030)$. Entretanto, no $14^{\circ} \mathrm{dia}$, a angiogênese foi mais pronunciada no Grupo Eletrocautério, mas sem significância estatística. Conclusão: a hemostasia alcançada pelos grupos foi semelhante; no entanto, o uso do eletrocautério esteve associado à infecções, aderências abdominais de graus mais elevados e à elevação das enzimas hepáticas.
\end{abstract}

Descritores: Hepatectomia. Ratos. Eletrocoagulação. Fibrina.

\section{REFERENCES}

1. Sampaio JA, Waechter FL, Passarin TL, Kruse CK, Nectoux M, Fontes PRO, et al. É possível diminuir o sangramento em hepatectomias sem a realização de exclusão vascular total ou parcial? Resultados do uso de radiofrequência bipolar em agulhas resfriadas. ABCD arq bras cir dig. 2011;24(2):159-63.

2. Araújo Lima AAL, Ramalho LNZ, Zucoloto $S$, Bagnato VS, Silva Júnior OC. Estudo das aminotransferases em ratos cirróticos hepatectomizados após aplicação de laser. Acta Cir Bras. 2001;16 (Suppl 1):44-6.

3. Paes-Barbosa FC, Ferreira FG, Szutan LA. Planejamento pré-operatório em hepatectomias. Rev Col Bras Cir. 2010;37(5):370-5.

4. Samudrala S. Topical hemostatic agents in surgery: a surgeon's perspective. AORN J. 2008;88(3):S2-11.

5. Nair SK, Bhat IK, Aurora AL. Role of proteolytic enzyme in the prevention of postoperative intraperitoneal adhesion. Arch Surg. 1974;108(6):849-53.

6. Arroyo Júnior $P C$, Silva RCMA, Santi Neto $D$, Santana Júnior $D$, Ferreira FD, Silva RF. Uso do subgalato de bismuto para hemostasia local em hepatectomias parciais em ratos. Rev Col Bras Cir. 2004;31(3)165-71.

7. Simões JC, Kamei DJ, Santos FMR, Alcala JMF, Rocha TJ. Avaliação da hemostasia do parênquima hepático utilizando eletrocautério emplastrado com gel de lidocaína ou loção glicerina em ratos Wistar. Rev Med Resid. 2011;13(3):1-12.

8. Guérios SD. Uso experimental de adesivo não cirúrgico de cianoacrilato nas hepatectomias parciais em cães [dissertação]. Curitiba: Universidade Federal do Paraná, Curso de Pós-Graduação em Ciências Veterinárias; 2000.
9. Lee KF, Wong J, Ng W, Cheung YS, Lai P. Feasibility of liver resection without the use of the routine Pringle manoeuver: an analysis of 248 consecutive cases. HPB. 2009;11(4):332-8.

10. Silva OC, Mente ED, Sankarankutty AK, Souza MEJ, Gomes MCJ, Picinato MANC, et al. Biochemical liver function after partial hepatic resection with or without partial hepatic vascular exclusion. Acta Cir Bras. 2011;26 (Suppl 2):120-4.

11. Oliveira AF, Castro e Silva T, Sankarankutty AK, Pacheco EG, Ferreira J, Bagnato VS, et al. The effect of laser on remanescent liver tissue after $90 \%$ hepatectomy in rats. Acta Cir Bras. 2006;21(Suppl 1):29-32.

12. Emanuelli MP, Lopes STA, Maciel RM, Garmatz BC, Tavares MO. Concentração sérica de fosfatase alcalina, gamaglutamiltransferase, ureia e creatinina em coelhos (Oryctolagus cuniculus). Cienc Anim Bras. 2008;9(1)251-5.

13. Carvalho MDF, Araújo-Filho I, Azevedo IM, Rêgo ACM, Medeiros AC. Metabolic and hematologic consequences of colectomy associated to hepatectomy in rats. Acta Cir Bras. 2011;26(6):5037.

Received on 04/04/2013

Accepted for publication 30/05/2013

Conflict of interest: none.

Source of funding: none.

Address for correspondence:

Tâmara Guimarães Rúbia Cavalcante Coutinho

E-mail: ipem@evangelico.org.br 